\title{
An enzyme-linked immunosorbent assay for the detection of IgG antibodies against Babesia equi in horses
}

\author{
Um ensaio imunoenzimático para a detecção de anticorpos IgG contra Babesia \\ equi em eqüinos
}

\author{
Cristiane Divan Baldani ${ }^{1}$ Rosangela Zacarias Machado ${ }^{2} \quad$ Paulo de Tarso Landgraf Botteon $^{3}$ \\ Felipe Santoro Takakura ${ }^{4}$ Carlos Luiz Massard $^{5}$
}

\section{ABSTRACT}

A crude antigenic preparation of Babesia equi was used to develop and establish the suitability of an enzyme-linked immunosorbent assay (ELISA) for the detection of parasite carriers. Optimal dilutions of the antigen, using positive and negative reference sera, were determined by checkboard titrations. The specificity and sensitivity of the ELISA were $100 \%$. A total of 90 serum samples were taken from horses from the Northeast region of São Paulo State and examined for diagnosis of equine B. equi infection by ELISA. Approximately $75 \%(n=67)$ of all the horses tested were found serologically positive for $B$. equi. These results suggest that the ELISA described may prove to be an appropriate serological test for epidemiological studies on $\boldsymbol{B}$. equi infections in the field and that equine piroplasmosis is a cause for serious concern in the State of São Paulo, Brazil.

Key words: Babesia equi, equine piroplasmosis, ELISA.

\section{RESUMO}

Um ensaio de imunoadsorção enzimática (ELISA) baseado em antígeno bruto de Babesia equi foi desenvolvido para a detecção de portadores crônicos de babesiose eqüina. As diluições ótimas do antígeno e dos soros controles positivo e negativo foram determinadas através de titulação em bloco. A sensibilidade e especificidade do teste foram de $100 \%$. O ELISA foi empregado em 90 soros de eqüinos da região Nordeste do Estado de São Paulo, de modo que aproximadamente $75 \%(n=67)$ dos eqüinos foram positivos para B. equi. Estes resultados sugerem que o ELISA descrito pode ser utilizado no diagnóstico sorológico de B. equi e que a piroplasmose eqüina é um problema sério no Estado de São Paulo, Brasil.
Palavras-chave: Babesia equi, piroplasmose eqüina, ELISA.

\section{INTRODUCTION}

Equine piroplasmosis or babesiosis is a tickborne protozoal disease caused by two intraerythrocytic parasites, Babesia equi and Babesia caballi. This illness affects horses, mules, donkeys and zebras and may occur in a acute, subacute or chronic form. The disease is characterized by fever, anemia, icterus, hepato and splenomegaly, intravascular hemolysis and petechial hemorrhages of the mucuous surfaces, and hemoglobinuria (SCHEIN, 1988).

The introduction of carriers into nonendemic areas must be prevented (SCHEIN, 1988) once equine babesiosis has posed a threat to the international movement of horses. Horses from a Babesia free zone, when introduced into an endemic area, suffer clinically from the disease resulting into death of large number of animals. Therefore, the development of a highly specific and sensitive diagnostic system for $\boldsymbol{B}$. equi is of urgent necessity.

Direct microscopic identification of the parasite in stained blood smears is confirmatory, but it is usually difficult to find the organism in carrier animals. Therefore, despite the high specificity, microscopic examination of blood smears are of low sensitivity for the detection of carrier animals.

\footnotetext{
${ }^{1}$ Médico Veterinário, Mestrando do Curso de Pós-graduação em Medicina Veterinária, Universidade Estadual Paulista (UNESP), Faculdade de Ciências Agrárias e Veterinária (FCAV).

${ }^{2}$ Médico Veterinário, Professor Titular, Departamento de Patologia Animal, UNESP, FCAV. Via de Acesso Professor Paulo Donato Castellane s/n, Jaboticabal-SP, CEP 14884-900. E-mail: zacarias@fcav.unesp.br

${ }^{3}$ Médico Veterinário, Professor Adjunto, Departamento de Clínica e Cirurgia, IV, Universidade Federal Rural do Rio de Janeiro (UFRRJ).

${ }^{4}$ Médico Veterinário, Mestrando do Curso de Pós-graduação em Medicina Veterinária, UNESP, FCAV.

${ }^{5}$ Médico Veterinário, Professor Titular, Departamento de Parasitologia Animal, IV, UFRRJ.
} 
Serological methods, such as complement fixation test (CFT) and the indirect fluorescent antibody test (IFAT) are commonly used for detecting $\boldsymbol{B}$. equi infections. However, these tests are generally restricted by antibody detection limits and cross reactivity (BRUNING, 1996; SCHEIN, 1988). More recently, an enzyme-linked immunosorbent assay (ELISA) using recombinant antigens has been suggested as an alternative to CFT and IFAT for the diagnosis of $\boldsymbol{B}$. equi infections (HIRATA et al., 2003; TANAKA et al., 1999; XUAN et al., 2001). Several other techniques including in vitro cultures, DNA probes, polymerase chain reaction, nested polymerase chain reaction and western blot analysis have been used for the diagnosis of B. equi. However, except for serology, these methods are laborious, expensive and timeconsuming.

It was the aim of our investigation to develop and establish the suitability of an enzymelinked immunosorbent assay using a crude antigen of B. equi for the detection of parasite carriers, as well as investigate the prevalence of equine piroplasmosis in the State of São Paulo, Brazil.

\section{MATERIAL AND METHODS}

\section{Source}

A Babesia equi strain isolated by MACHADO(1993)(Personal Communication) from a foal of 8 days of birth at UNESP-FCAV, Jaboticabal, State of São Paulo, Brazil, was utilized in this study. The isolate was maintained cryopreserved in $10 \%$ dimethyl sulphoxide in liquid nitrogen at Universidade Estadual de São Paulo. For the preparation of B. equi ELISA antigen, a two year old horse, free from hemoparasites, was splenectomized and inoculated intravenously with cryopreserved $\boldsymbol{B}$. equi and monitored daily for the presence of parasites by microscopic examination of Giemsa stained blood smears. Infected blood was collected in an equal volume of Alsever solution during the peak of parasitaemia, approximately $80 \%$, which occurred on the ninth day after inoculation. The blood was diluted 1:4 in normal saline and the infected erythrocytes subjected to lyses with ammonion chloride (MACHADO et al., 1994). B. equi free merozoites were disrupted by nine freezing $\left(-70^{\circ} \mathrm{C}\right) /$ thawing cycles $\left(37^{\circ} \mathrm{C}\right)$, lyophilized and stored at $-70^{\circ} \mathrm{C}$ until required for the ELISA test.

\section{Serum samples}

A sera panel of known origin, including 15 serum samples from foals before they suckled colostrum were collected. These sera were considered negative controls. A positive reference group consisting of 15 sera samples tested positive for $\boldsymbol{B}$. equi by IFAT and 15 anti-B. caballi IFAT positive/B. equi negative sera samples were also used. Sera from 90 horses of the Northeast region of São Paulo State collected at random between 1998 and 1999 were also examined.

\section{ELISA procedure}

The ELISA method was essentially as described by MACHADO et al. (1997), although with minor modifications. Briefly, $100 \mu$ l of crude B. equi antigen diluted in a sodium bicarbonate-carbonated $0.05 \mathrm{M}$ buffer ( $\mathrm{pH}$ 9.6) was added to each well of a micro-ELISA plate (Nunclon ${ }^{\mathrm{TM}}$ Surface; Nunc, Denmark) and protein concentration was adjusted to $5 \mu \mathrm{g} \mathrm{ml}^{-1}, 10 \mu \mathrm{g} \mathrm{ml}^{-1}, 20 \mu \mathrm{g} \mathrm{ml}^{-1}$ and $40 \mu \mathrm{g} \mathrm{ml}^{-1}$. After overnight incubation at $4^{\circ} \mathrm{C}$, the excess of antigen was removed by three washes with PBS Tween-80 at $0.05 \%$. To reduce non-specific binding, the plates were blocked with $200 \mu \mathrm{l}$ of PBS Tween-80 containing 6\% skim milk for 2 hours at $37^{\circ} \mathrm{C}$. The blocking agent was removed, and individual horse serum diluted (1:100 to 1:3200) in PBS Tween-80 with 5\% skim milk (PBS-TW-SM) was added to each well and then incubated for 90 minutes at $37^{\circ} \mathrm{C}$. Unbound antibodies were removed by washing the plates as described above. One hundred $\mu 1$ of alkaline phosphatase conjugated anti-horse IgG (Sigma Chemical Co.) diluted 1:15000 in PBS-TW-SM were added to each well and then incubated for 90 minutes at $37^{\circ} \mathrm{C}$. The plates were washed and the appropriate substrate (pnitrophenyl phosphate) was added. Absorbance at $405 \mathrm{~nm}$ was read after 45 minutes incubation at room temperature using an ELISA reader (Dynex Technologies).

Optimal dilutions of antigen and positive and negative sera were determined by checkboard titrations (MACHADO et al., 1997). The immunological activity of each serum was calculated by determining the sample to positive serum ratio (S/ $\mathrm{P})$, considering positive and negative sera as reference, using the following equation:

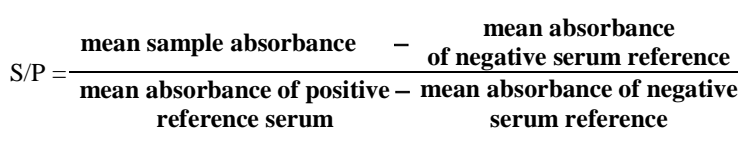

$\mathrm{S} / \mathrm{P}$ values were grouped into ELISA levels (EL), which ranged from 0 (lowest level) to 9 (highest 
level), as described by MACHADO et al. (1997). The discriminant absorbance value (cut-off) was determined as being two and a half times the mean absorbance value of the negative group, where readings above the cutoff value were considered positive. Specificity was defined as the proportion of known negative serum samples detected as negative and the sensitivity was defined as the proportion of known positive serum samples detected as positive.

\section{RESULTS}

Checkerboard titrations showed a antigen concentration of $10 \mu \mathrm{g} \mathrm{mL}^{-1}$ in carbonate buffer, $\mathrm{pH}$ 9.6, as optimum. Serum samples were diluted at 1:100. The average absorbance of negative sera was $0.111 \pm$ 0.021 , resulting in a calculated cut-off value of 0.278 (EL 2 - Table 1). Absorbance values observed with anti-B. caballi sera were lower $(0.136 \pm 0.021)$ than the defined cutoff value. The mean absorbance value of the anti-B. equi serum group $(0.997 \pm 0.146)$ was approximately 8.9 times greater than that obtained with non-infected sera, clearly discriminating between the mean absorbances of the positive and negative reference sera. This data gave a sensitivity and specificity of $100 \%$. All serum samples from 15 horses infected with $B$. equi were positive, whereas serum samples from all 15 known negative horses and 15 horses infected with B. caballi were negative. The EL were determined as shown in table 1.

Titres of antibodies against $\boldsymbol{B}$. equi crude antigen were determined in sera collected from 90 field horses in the State of São Paulo. The results of the number of sera distributing through EL are shown in figure 1 . Mean absorbance value of $\mathrm{S} / \mathrm{P}$ was 0.728 (EL 6). The estimated ELISA values demonstrated that $75 \%$ of the horses had EL 2-9, with only $25 \%$ of the serum samples being negative for $\boldsymbol{B}$. equi infection. It should be mentioned that $17.78 \%$ $(n=16)$ of the horses tested, which had low antibody levels for B. equi (EL 2, 3 and 4), were diagnosed as positive.

\section{DISCUSSION AND CONCLUSIONS}

The ELISA described in this paper is based on the use of reference sera to clearly define the difference between negative and positive sera and to calibrate ELISA absorbance as a score over a wide range of antibody levels. Additionally, the antigenic preparation was produced using a very simple methodology and required little material manipulation at a very low cost. The results have demonstrated that a crude soluble antigen prepared from infected erythrocytes could be used in a sensitive and specific ELISA to detect antibodies to $\boldsymbol{B}$. equi.

Good crude antigenic preparations of intracellular parasites are difficult to produce, particularly due to the presence of host contaminant components, such as red blood fragments. These contaminants make the standardization of immunological assays a crucial step (MAHONEY \& GOODGER, 1981) since they increase the occurrence of non-specific reactions. ZWART \& BROKLESBY (1979) suggests that the technique adopted for the preparation of Babesia antigen is crucial and has an important role on the specificity/cross-reactivity of the diagnosis test.

The detection of specific antibodies by various serological methods has been recognized as the method of choice for the identification of $\boldsymbol{B} . \boldsymbol{e q u i}$ infected animals, especially those persistently infected, which are subject to restrictions in international commerce. Moreover, these methods facilitates the testing of large number of animals for epidemiological studies. Currently, regulatory control of equine babesiosis in the USA, Brazil, Canada, Japan and Australia, relies on serological tests. The CFT and IFAT are the most frequently used techniques for the detection of antibodies to B. equi. However, both tests present some disadvantages. The CFT is unable to detect a latent infection and it fails to accurately discriminate between negative and carrier animals (TENTER \& FRIEDHOFF, 1986), in addition to requiring large quantities of antigen prepared from the erythrocytes of infected horses to carry out large scale seroepidemiological surveys. In the IFAT, on the other hand, standardization is difficult considering the subjective judgement of the reader (BOSE et al., 1995; BRUNING, 1996) and it is a time-consuming method.

The development of an ELISA which can be an alternative to CFT and IFAT has been the aim of

Table 1 - S/P values for EL 0-9

\begin{tabular}{ll}
\hline EL & $\mathrm{S} / \mathrm{P}$ \\
\hline 0 & $0,000-0,154$ \\
1 & $0,155-0,208$ \\
2 & $0,209-0,281$ \\
3 & $0,282-0,379$ \\
4 & $0,380-0,512$ \\
5 & $0,513-0,691$ \\
6 & $0,692-0,933$ \\
7 & $0,934-1,260$ \\
8 & $1,261-1,701$ \\
9 & $\geq 1,702$ \\
\hline
\end{tabular}

Ciência Rural, v.34, n.5, set-out, 2004. 


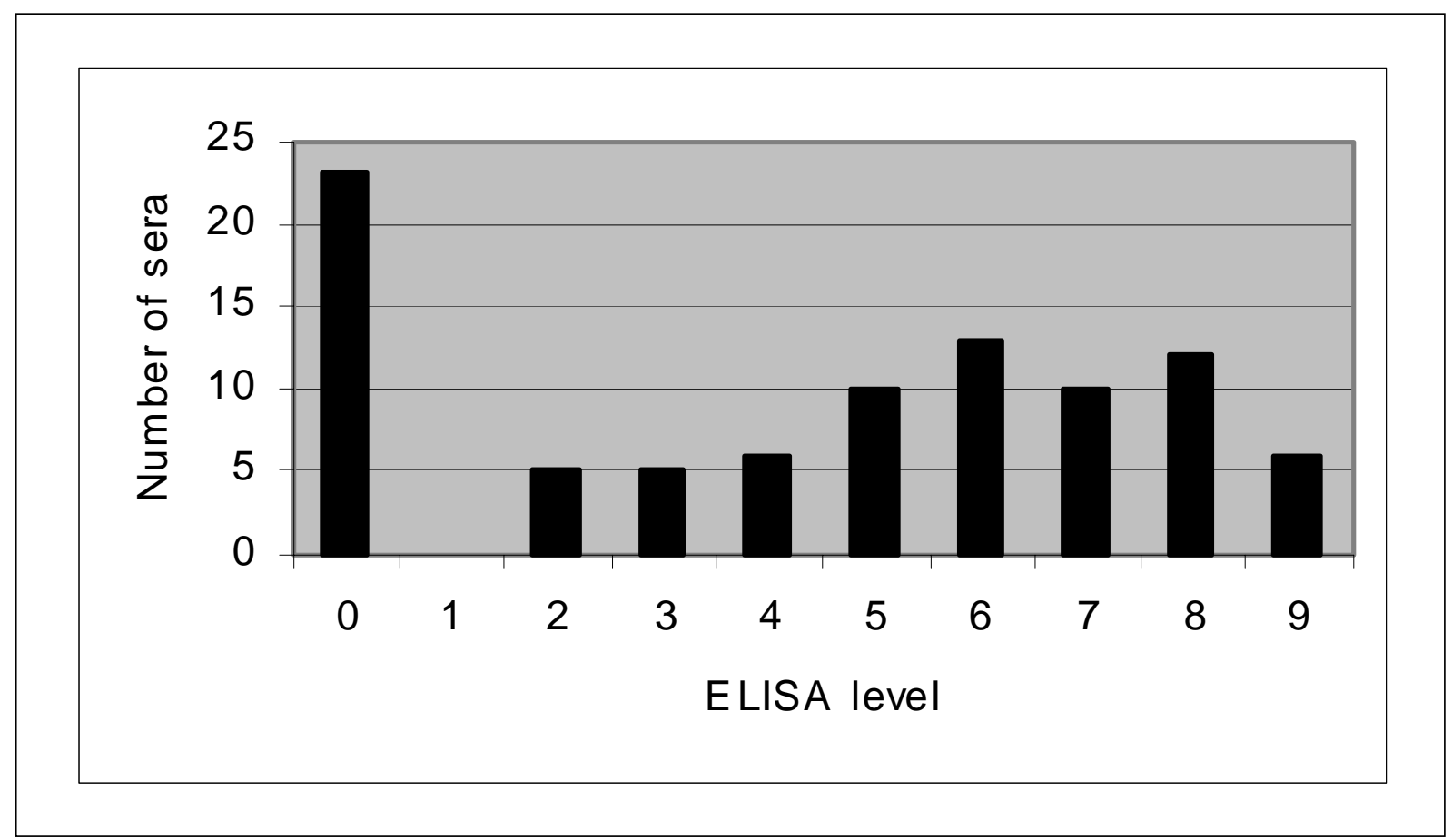

Figure 1 - Number of sera from horses $(\mathrm{n}=90)$ raised in the Northeast region of São Paulo State, screened by ELISA against $\boldsymbol{B}$. $\boldsymbol{e q u i}$ crude soluble antigen and plotted by ELISA level (EL).

many studies. A competitive inhibition ELISA, employing a specific monoclonal antibody and a recombinant $\boldsymbol{B}$. equi merozoite protein (EMA-1), was shown to be specie-specific for anti-B. equi antibodies, as horses infected with $\boldsymbol{B}$. caballi tested negative (KNOWLES et al., 1991). It has been shown that an ELISA using recombinant EMA-1 expressed in insect cells by baculovirus can be a useful diagnostic reagent for detection of $\boldsymbol{B}$. equi infection in horses (XUAN et al., 2001), being more sensitive than CFT and IFAT. Moreover, recombinant merozoite antigen-2 (EMA2) was used as the source of antigen in an ELISA developed for the detection of antibodies anti-B. equi (TANAKA et al., 1999). More recently, the identification of a specific antigenic region of the Be82 gene allowed the development of a novel ELISA with an antigen (GST/Be82/236-381) that proved to have specificity and sensitivity for $\boldsymbol{B}$. equi antibodies of $100 \%$ (HIRATA et al., 2003). However, the use of recombinant antigens in the diagnosis of equine piroplasmosis has a high cost when compared to crude antigenic preparations. Additionally, the use of antigens produced from $\boldsymbol{B}$. equi brazilian strains, as in our study, eliminates possible antigenic differences existent between isolates from different regions.

The study of the humoral response in sera from brazilian horses has shown that equine piroplamosis is a serious problem in Brazil. In Rio de Janeiro State, PFEIFER-BARBOSA et al. (1993) detected antibodies anti-B. equi in $100 \%$ of the serum samples analyzed by IFAT and $96,7 \%$ by CFT. BOTTEON (1996) recorded prevalence of $73 \%$ for B. equi by IFAT, whereas BITTENCOURT \& MASSARD (1997) observed seropositive rates of $84.6 \%$ by CFT in then same region of Rio de Janeiro. HEUCHERT et al. (1999) tested 752 serum samples from São Paulo State by IFAT and CFT and reported prevalence rates of $29.6 \%$ and $17.6 \%$, respectively. Serum samples from horses in different regions of Brazil were tested by TFC in order to determine the prevalence of equine babesiosis, which was $42.48 \%$ for $\boldsymbol{B}$. equi and $33.77 \%$ for $\boldsymbol{B}$. caballi (KERBER et al., 1999). Recently, XUAN et al (2001) recorded prevalence of $81 \%$ for B. equi infection in the States of São Paulo and Mato Grosso do Sul, Brazil. Although our results demonstrated a significantly higher prevalence for $\boldsymbol{B}$. equi than that reported by HEUCHERT et al. (1999) in the State of São Paulo, they are in accordance with those published by XUAN et al. (2001). We suggest that the differences observed could be explained by the serological tests used.

In conclusion, the developed ELISA system for detection of anti-B. equi IgG antibodies 
proved to have sensitivity and shows to be an appropriate test for epidemiological studies in endemic areas. Besides, the results indicates that equine babesiosis is widespread and therefore a cause for serious concern in the State of São Paulo, Brazil.

\section{ACKNOWLEDGEMENTS}

This study was supported by grants from the Fundação de Amparo à Pesquisa do Estado de São Paulo (FAPESP), Brazil.

\section{REFERENCES}

BITTENCOURT, V.R.E.P.; MASSARD, C.L. Aspectos epidemiológicos da babesiose equina na Microregião Fluminense do Grande Rio-Itaguaí, Estado do Rio de Janeiro. Revista Brasileira de Ciência Veterinária, Niterói, v.4, n.1, p.13-17, 1997.

BOtTEOn, P.T.L. Aspectos epidemiológicos e influência dos sistemas de criação de eqüinos na prevalência de Babesia equi (Laveran, 1901). 1996. 96f. Dissertação (Mestrado em Medicina Veterinária) - Universidade Federal Rural do Rio de Janeiro, Seropédica.

BOSE, R. et al. Current state and future trends in the diagnosis of babesiosis. Veterinary Parasitology, Amsterdam, v.57, p.61-74, 1995.

BRUNING, A. Equine piroplasmosis an update on diagnosis, treatment and prevention. British Veterinary Journal, London, v.152, p.139-151,1996.

HEUCHERT, C.M. et al. Seroepidemiologic studies on Babesia equi and Babesia caballi infections in Brazil. Veterinary Parasitology, Amsterdam, v.85, n.1, p.1-11, 1999.

HIRATA, H. et al. Identification of a specific antigenic region of the P82 protein of Babesia equi and its potential use in serodiagnosis. Journal of Clinical Microbiology, Washington, v.41, n.2, p.547-551, 2003.
KERBER, C.E.; FERREIRA, F.; PEREIRA, M.C. Control of equine piroplasmosis in Brazil. Onderstepoort Journal of Veterinary Research, Petroia, v.66, n.2, p.123-127, 1999.

KNOWLES, D.P. et al. Detection of equine antibody to Babesia equi merozoite protein by a monoclonal antibody based competitive inhibition enzyme linked immunosorbent assay. Journal of Clinical Microbiology, Washington, v. 29, p.20562058, 1991.

MACHADO, R.Z. et al. Isolation of Babesia bigemina and Babesia bovis merozoites by ammonium chlorid lysis of infected erythrocytes. Brazilian Journal of Medical Biological Research, Ribeirão Preto, v.27, p.2591-2598, 1994.

MACHADO, R.Z. et al. An enzyme-linked immunosorbent assay (ELISA) for the detection of antibodies against Babesia bovis in cattle. Veterinary Parasitology, Amsterdam, v. 71, p.17-26, 1997.

MAHONEY, D.F.; GOODGER, B.V. The isolation of Babesia parasites and their products from the blood. In: RISTIC, M., KREIER, J.P. (Ed.). Babesiosis. New York: Academic, 1981. p.323-332.

PFEIFER BARBOSA, I. et al. Epidemiological aspects of equine babesioses in a herd of horses in Brazil. Veterinary Parasitology, Amsterdam, v.58, n.1-2, p.1-8, 1995.

SCHEIN, E. Equine babesiosis. In: RISTIC, M. (Ed.).Babesiosis of domestic animals and man. Boca Raton: CRS,1988. p. 197-208.

TANAKA, T. et al. Expression of Babesia equi merozoite antigen2 by recombinant baculovirus and its use in the ELISA. International Journal for Parasitology, Oxford, v.29, n.11, p.1803-1808, 1999.

TENTER, A.M.; FRIEDHOFF, K.T. Serodiagnosis of experimental and natural Babesia equi and B. caballi infections. Veterinary Parasitology, Amsterdam, v.20, n.1-3, p.49-61, 1986.

XUAN, X. et al. Diagnosis of equine piroplasmosis in Brazil by serodiagnostic methods with recombinant antigens. Journal of Veterinary Medical Science, v.63, n.10, p.1159-60, 2001.

ZWART, D.; BROCKLESBY, D.W. Babesiosis: non-specific resistance, immunological factors and pathogenesis. Advances in Parasitology, London, v.17, p.49-113, 1979. 